\title{
Immunohistochemical localisation of $\mathrm{d}^{2}$-aspartic acid-containing proteins in climatic droplet keratopathy
}

Y Kaji, T Oshika, Y Takazawa, M Fukayama and N Fujii

Br. J. Ophthalmol. 2009;93;977-979; originally published online 9 Mar 2009;

doi:10.1136/bjo.2008.144212

Updated information and services can be found at:

http://bjo.bmj.com/cgi/content/full/93/7/977

These include:

References This article cites 24 articles, 6 of which can be accessed free at:

http://bjo.bmj.com/cgi/content/full/93/7/977\#BIBL

Rapid responses You can respond to this article at:

http://bjo.bmj.com/cgi/eletter-submit/93/7/977

Email alerting Receive free email alerts when new articles cite this article - sign up in the box at service the top right corner of the article

Topic collections Articles on similar topics can be found in the following collections

Cornea (297 articles)

Ocular surface (359 articles)

\section{Notes}

To order reprints of this article go to:

http://journals.bmj.com/cgi/reprintform

To subscribe to British Journal of Ophthalmology go to:

http://journals.bmj.com/subscriptions/ 


\title{
Immunohistochemical localisation of $\mathrm{D}$ - $\beta$-aspartic acid-containing proteins in climatic droplet keratopathy
}

\author{
Y Kaji, ${ }^{1}$ T Oshika, ${ }^{1}$ Y Takazawa, ${ }^{2}$ M Fukayama, ${ }^{2}$ N Fujii ${ }^{3}$
}

${ }^{1}$ Department of Ophthalmology, Tsukuba University Institute of Clinical Medicine, Ibaraki, Japan;

${ }^{2}$ Department of Pathology, University of Tokyo Graduate School of Medicine, Tokyo, Japan; ${ }^{3}$ Research Reactor Institute, Kyoto University, Kumatori, Sennan, Osaka, Japan

\section{Correspondence to:}

Dr Y Kaij, Department of Ophthalmology, Tsukuba University Institute of Clinical

Medicine, Tennoudai 1-1-1,

Tsukuba, Ibaraki 305-8575,

Japan; sanken-tky@umin.ac.jp

Accepted 13 December 2008 Published online First

9 March 2009

\section{ABSTRACT}

Aim: Biologically uncommon D- $\beta$-aspartic acid (D- $\beta$-Asp) accumulates in the body with age and is involved in the ageing process. In the present study, the localisation of D$\beta$-Asp-containing proteins was investigated in surgical specimens with climatic droplet keratopathy (CDK), one of the ocular changes related to the ageing process.

Methods: Immunohistochemical localisation of D- $\beta$-Aspcontaining proteins using polyclonal antibodies raised against $\mathrm{D}$ - $\beta$-Asp-containing peptides was examined in three corneas with CDK, three corneas with interstitial keratitis, six corneas with bullous keratopathy, and three corneas without any corneal diseases.

Results: Strong immunoreactivity to D- $\beta$-Asp-containing peptide was detected in all the surgical specimens with CDK. In contrast, no immunoreactivities to D- $\beta$-Aspcontaining peptides were detected in the surgical specimens with bullous keratopathy, interstitial keratitis, or no corneal diseases.

Conclusions: CDK was regarded as aggregations of D- $\beta$ Asp-containing proteins. The formation of D-amino acids in protein causes the different side chain orientations and $\beta$ linkage of Asp residues elongates the main chain of proteins. Therefore, $\mathrm{D}-\beta$-Asp formation will result in a partial unfolding of proteins leading to the aggregation of proteins seen in CDK.

Climatic droplet keratopathy (CDK), also known as spheroid degeneratation of the cornea, is common and is one of the leading causes of blindness especially elderly people living in equatorial and polar regions. ${ }^{1}$ For example, CDK accounts for $57 \%$ of all the cases of blindness in the Dahlak Islands located in the Red Sea. ${ }^{2}$ Epidemiological studies have confirmed that ultraviolet irradiation and age are closely related to the development of CDK. ${ }^{1}$ Histological studies have shown the accumulation of amorphous materials especially in the superficial layer of the cornea with CDK. However, the nature of the amorphous materials and the pathogenesis of CDK are still unclear.

One of the molecular mechanisms of ageing process is the formation of D-amino acids. Although protein of all living organisms are composed exclusively of L-amino acids, biologically uncommon D-amino acids, that is enantiomer of Lamino acid, has been recognised as a molecular basis of diseases related to ultraviolet irradiation and ageing process. ${ }^{3}$ D-aspartic acids (D-Asp) were found in the lenses, ${ }^{3-6}$ teeth, ${ }^{78}$ bones, ${ }^{9}$ brains, ${ }^{10}$ skin, ${ }^{11}$ aortas, ${ }^{12}$ erythrocytes, ${ }^{13}$ lungs, ${ }^{14}$ and ligaments of elderly donors. ${ }^{8}$ The presence of D-Asp in aged tissues of the living body is considered to be a result of racemisation of L-Asp in proteins in such metabolically inert tissues during one's life time. In addition, D-aspartic acid in living organisms is considered to be not only an index of ultraviolet irradiation but also a useful marker of the ageing process

This study was undertaken to reveal the contribution of $\mathrm{D}$-Asp in the pathogenesis of CDK. To this end, the immunohistochemical localisation of $\mathrm{D}-\beta$-Asp-containing proteins was investigated in surgical specimens with CDK.

\section{MATERIALS AND METHODS}

Surgical specimens of cornea with or without climatic droplet keratopathy

Informed consent was obtained from all the patients undergoing corneal surgery in the present study. Reviewing all the corneal specimens submitted to the department of pathology, University of Tokyo from April 1994 to January 2008, we have found three corneas with CDK from three patients (two male and one female, 62.0 (SD 4.0) years old). One male patient had no past history of keratitis, indicating that the patient had primary CDK. The others had past histories of interstitial keratitis with congenital syphilis, indicating that they had secondary CDK. Appropriate slit-lamp images of the corneas of the patients with CDK were not obtained. In addition, six corneas with bullous keratopathy from six patients (four male and two female, 58.3 (8.4) years old), three corneas with interstitial keratitis (two male and one female, 59.7 (9.0) years old) and three corneas without any corneal diseases (two male and one female, 66.0 (6.2) years old) were obtained. Haematoxylin-eosin staining and immunohistochemistry described as follows were performed on all the surgical specimens.

\section{Antibody against D- $\beta$-aspartic acid-containing peptides}

The preparation and characterisation of the polyclonal antibody against D- $\beta$-Asp-containing peptides have been previously described. ${ }^{411}$ The polyclonal antibody against the peptide, Gly-LeuD- $\beta$-Asp-Ala-Thr-Gly-Leu-D- $\beta$-Asp-Ala-Thr-GlyLeu-D- $\beta$-Asp-Ala-Thr (antipeptide 3R antibody), which corresponds to three repeats of positions 149-153 of human $\alpha$-A-crystallin, was prepared and purified as described by Fujii et al. The antibody clearly distinguished the configuration of the Asp-residue, that is, it reacted strongly with the $\mathrm{D}-\beta$-Asp-containing peptides but did not react with the L- $\alpha$-Asp, L- $\beta$-Asp, or D- $\alpha$-Asp-containing peptides. $^{411}$ 

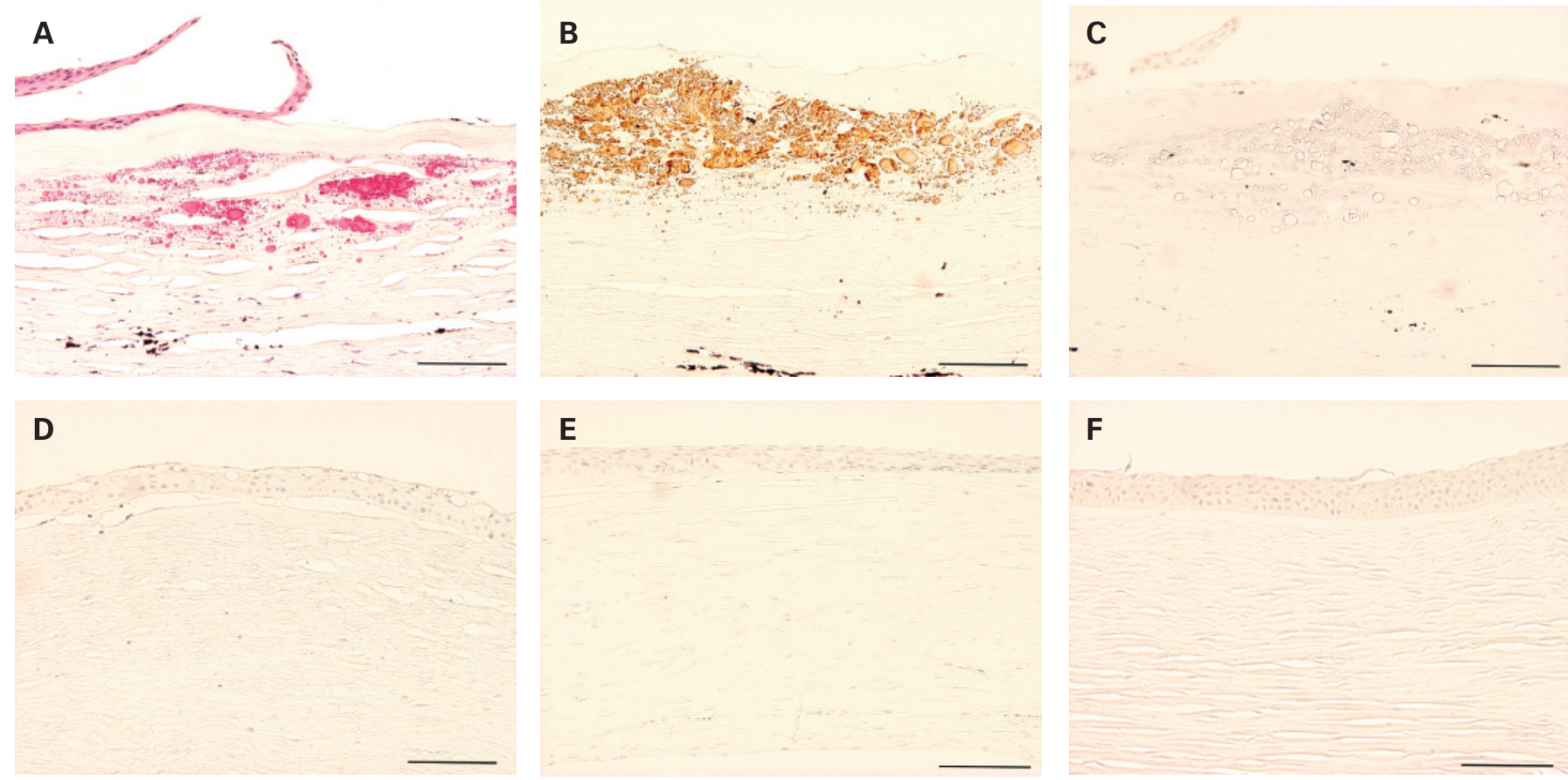

Figure 1 Immunohistochemical localisation of $\mathrm{D}-\beta$-aspartic acid-containing protein. Eosinophilic and amorphous materials are observed in the superficial layer of the corneal stroma (A) with CDK. The materials were positive for D- $\beta$-Asp (B). Incubation with D- $\beta$-Asp-containing peptide in the reaction mixture almost completely blocked the immunoreaction (C). No immunoreaction was observed in cornea with bullous keratopathy (D), interstitial keratitis (E) or corneas without any corneal diseases (F). In all figures, bar $=100 \mu \mathrm{m}$.

\section{Immunohistochemistry}

Immunohistochemical localisation of D- $\beta$-Asp-containing peptides was investigated using the antibody mentioned earlier. ${ }^{11} 15{ }^{16}$ Briefly, the surgical specimens were fixed with $4 \%$ paraformaldehyde (Sigma, St Louis, Missouri) in $0.1 \mathrm{M}$ phosphate buffer ( $\mathrm{pH}$ 7.4) for $24 \mathrm{~h}$. After embedding in paraffin, 4$\mu \mathrm{m}$-thick sections of samples were prepared. Following deparaffinisation, the sections were treated with a polyclonal antibody to D- $\beta$-Asp-containing peptides at a dilution of 1:500 dissolved with phosphate-buffered saline (PBS) containing 1\% normal bovine serum albumin and kept at $4^{\circ} \mathrm{C}$ overnight. After washing the section with PBS, the samples were treated with the reaction solution containing a secondary antibody labelled with horseradish peroxidase (Histofine Max-PO kit: NICHIREI, Tokyo) and kept for $30 \mathrm{~min}$ at room temperature. The sections were then incubated with diaminobenzidine (Sigma) in PBS. Finally, the sections were counterstained with haematoxylin. As a negative control, the primary antibody was replaced with normal rabbit serum IgG $(1.0 \mu \mathrm{g} / \mathrm{ml})$ diluted in PBS containing $1 \%$ bovine serum albumin (Sigma).

To evaluate the specificity of the binding of the primary antibody to D- $\beta$-Asp-containing peptides, the sections were incubated with the mixture of the primary antibody and $10 \mu \mathrm{g} /$ $\mathrm{ml}$ of peptide $3 \mathrm{R}$ instead of using the primary antibody alone. Then, the samples were treated with the secondary antibody followed by diaminobenzidine in PBS.

The results of the immunohistochemistry were checked and graded in double-blinded manner.

\section{RESULT}

Examples of haematoxylin-eosin staining and immunohistochemistry in a cornea with $\mathrm{CDK}$ are shown in fig 1 . In specimens of CDK, numerous eosinophilic amorphous materials were observed in the superficial layer of the corneal stroma (fig 1A). Strong immunoreactivity to D- $\beta$-Asp was detected in the amorphous materials in the superficial layer of the cornel stroma (fig 1B). Incubation with D- $\beta$-Asp-containing peptides (peptide 3R) in the reaction mixture almost completely blocked the immunoreactivity to $D-\beta$-Asp (fig $1 \mathrm{C}$ ).

In corneal specimens with bullous keratopathy (fig 1D), interstitial keratitis (fig 1E) or no corneal diseases (fig 1F), immunoreactivity to D- $\beta$-Asp was not detected.

\section{DISCUSSION}

This study was undertaken to reveal the nature of amorphous materials seen in CDK in relation to D-amino acid. D- $\beta$-Aspcontaining proteins exist in the amorphous materials in CDK. A previous study has shown that the amorphous materials in $\mathrm{CDK}$ are aggregations of proteins that contain advanced glycation end-products (AGEs) including $\mathrm{N}^{\varepsilon}$-(carboxy)methylL-lysine, pyrraline, pentosidine and imidazolone. ${ }^{16}$ Taken together, the formation and accumulation of AGEs and D- $\beta$ Asp-containing proteins underlie the pathogenesis of CDK.

The localisation of AGEs and D-amino acids containing proteins in tissues seems to be common. First, ultraviolet irradiation accelerates the formation of AGEs and D-amino acids. Second, AGEs and D-amino-acid-containing proteins accumulate with age and are involved in the pathogenesis of age-related disorders. Third, the formation of AGEs and Damino acids induces aggregation of and major structural changes in the proteins. Fourth, the first step of AGE formation, the Maillard reaction, is known to accelerate the formation of Damino acids. ${ }^{17}$ In addition, AGEs and D-amino acids are known to colocalise in various pathological conditions including cataract, ${ }^{3-6}$ drusens ${ }^{6}{ }^{18}$ and actinic keratosis. ${ }^{11}$

The role of D-amino acids in the pathogenesis of age-related diseases has been extensively analysed in the lens. ${ }^{4519-21}$ Cataract formation is one of the most prominent age-related 
changes in the lens. Various post-translational modifications including AGE formation, racemisation of aspartic residues and the formation of disulfide bridges occur in lens proteins. ${ }^{22}$ These molecular modifications result in structural changes in the lens proteins and in the formation of high-molecular-weight protein aggregates. Among them, racemisation and isomerisation of aspartyl residues and their resultant D- $\beta$-Asp formation may affect the aggregation of protein because the side chain of orientation of $\mathrm{D}$-Asp residues turns upside down, and the main chain of the peptide bond contain $\beta$-linkage is elongated. ${ }^{4}{ }^{20}$

With the antibody, the accumulation of $\mathrm{D}$ - $\beta$-Asp-containing proteins in skin and various parts of eyes including the lens, sclera, ciliary epithelium, internal limiting membrane, lamina cribrosa and drusens has been reported. ${ }^{6}$ In the present study, we have shown the accumulation of $\mathrm{D}$ - $\beta$-Asp-containing proteins in CDK but not in corneas with bullous keratopathy, interstitial keratitis or no corneal diseases. However, D- $\beta$-Aspcontaining proteins may spread to a wider area because the antibody to peptide $3 \mathrm{R}$ does not recognise all the D- $\beta$-Aspcontaining peptides in tissue. For this reason, HPLC and spectrometry as well as immunohistochemistry are needed to investigate the role of D-amino acids in ageing processes.

Accumulation of D-amino acids has been regarded as a cause of the ageing process. This indicates that the inversion of L- to Damino acids or the breakdown of D-amino-acid-containing proteins will have a therapeutic effect on CDK. The ubiquitin and proteasome systems may serve to break down intracellular D-amino-acid-containing proteins. ${ }^{23}$ In addition, Kinouchi et al have reported that D-aspartyl end peptidase, which cleaves DAsp-containing peptide, is detected in various tissues including liver, kidney, spleen and lung. ${ }^{24}$ These systems serve as an endogenous protective mechanism against the accumulation of D-amino-acid-containing proteins in tissue. The regulation of these systems will be a clue to prevention and treatment of agerelated disorders including $\mathrm{CDK}$.

Funding: This work is supported by the Ministry of Education, Science, Sports and Culture, Grant-in-Aid for Young Scientists, 18791259 (2006-2008) and for Scientific Research, 21592216 (2009-2011), Japan.

Competing interests: None.

Ethics approval: Ethics approval was provided by Yuichi Kaji.

Patient consent: Obtained.

\section{REFERENCES}

1. Gray RH, Johnson GJ, Freedman A. Climatic droplet keratopathy. Surv Ophthalmol 1992; 36:241-53.

2. Rodger FC. Clinical findings, course, and progress of Bietti's corneal degeneration in the Dahlak islands. Br J Ophthalmol 1973;57:657-64.

3. Fujii N. D-amino acid in elderly tissues. Biol Pharm Bull 2005;28:1585-9.

4. Fujii N, Shimo-Oka T, Ogiso $\mathbf{M}$, et al. Localization of biologically uncommon o- $\beta$ aspartate-containing $\alpha A$-crystallin in human eye lens. Mol Vis 2000;6:1-5.

5. Masters PM, Bada JL, Zigler JS Jr. Aspartic acid racemisation in the human lens during ageing and in cataract formation. Nature 1977;268:71-3.

6. Kaji Y, Oshika T, Takazawa Y, et al. Localization of D- $\beta$-aspartic acid-containing proteins in human eyes. Invest Ophthalmol Vis Sci 2007;48:3923-7.

7. Masters PM. Stereochemically altered noncollagenous protein from human dentin Calcif Tissue Int 1983;35:43-7.

8. Ritz-Timme S, Laumeier I, Collins M. Age estimation based on aspartic acid racemization in elastin from the yellow ligaments. Int J Legal Med 2003;117:96-101.

9. Ohtani S, Yamamoto T, Matsushima Y, et al. Changes in the amount of D-aspartic acid in the human femur with age. Growth Dev Aging 1998;62:141-8.

10. Shapira R, Chou $\mathrm{CH}$. Differential racemization of aspartate and serine in human myelin basic protein. Biochem Biophys Res Commun 1987;146:1342-9.

11. Fujii N, Tajima S, Tanaka N, et al. The presence of D- $\beta$-aspartic acid-containing peptides in elastic fibers of sun-damaged skin: a potent marker for ultraviolet-induced skin aging. Biochem Biophys Res Commun 2002;294:1047-51.

12. Powell JT, Vine N, Crossman M. On the accumulation of D-aspartate in elastin and other proteins of the ageing aorta. Atherosclerosis 1992;97:201-8.

13. McFadden PN, Clarke S. Methylation at D-aspartyl residues in erythrocytes: possible step in the repair of aged membrane proteins. Proc Natl Acad Sci USA 1982; 79:2460-4.

14. Shapiro SD, Endicott SK, Province MA, et al. Marked longevity of human lung parenchymal elastic fibers deduced from prevalence of D-aspartate and nuclear weapons-related radiocarbon. J Clin Invest 1991;87:1828-34.

15. Miura Y, Fujimoto N, Komatsu T, et al. Immunohistochemical study of chronological and photo-induced aging skins using the antibody raised against D-aspartyl residuecontaining peptide. J Cutan Pathol 2004;31:51-6.

16. Kaji Y, Nagai R, Amano S, et al. Advanced glycation end product deposits in climatic droplet keratopathy. Br J Ophthalmol 2007:91:85-8.

17. Bruckner H, Justus J, Kirschbaum J. Saccharide induced racemization of amino acids in the course of the Maillard reaction. Amino Acids 2001;21:429-33.

18. Ishibashi T, Murata T, Hangai M, et al. Advanced glycation end products in agerelated macular degeneration. Arch Ophthalmol 1998;116:1629-32.

19. Fujii N, Harada K, Momose Y, et al. D-amino acid formation induced by a chiral field within a human lens protein during aging. Biochem Biophys Res Commun 1999;263:322-6.

20. Fujii N, Momose $\mathrm{Y}$, Ishii N, et al. The mechanisms of simultaneous stereoinversion, racemization, and isomerization at specific aspartyl residues of aged lens proteins. Mech Ageing Dev 1999;107:347-58.

21. Fujii N, Satoh K, Harada K, et al. Simultaneous stereoinversion and isomerization at specific aspartic acid residues in alpha A-crystallin from human lens. J Biochem 1994;116:663-9.

22. Groenen PJ, Merck KB, de Jong WW, et al. Structure and modifications of the junior chaperone $\alpha$-crystallin. From lens transparency to molecular pathology. Eur J Biochem 1994:225:1-19.

23. Hipkiss AR. Accumulation of altered proteins and ageing: causes and effects. Exp Gerontol 2006;41:464-73.

24. Kinouchi T, Nishio H, Nishiuchi $Y$, et al. Isolation and characterization of mammalian D-aspartyl endopeptidase. Amino Acids 2007;32:79-85. 